\title{
THE EMPIRICAL LINKAGE BETWEEN \\ OIL PRICES AND THE STOCK RETURNS OF OIL COMPANIES
}

Josef Pavlata $^{1}$, Petr Strejček ${ }^{1}$, Peter Albrecht ${ }^{1}$, Martin Širůček ${ }^{1}$

${ }^{1}$ Mendel University in Brno, Czech Republic

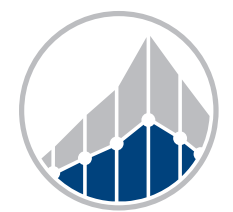

EUROPEAN JOURNAL OF BUSINESS SCIENCE AND TECHNOLOGY

Volume 7 Issue 2

ISSN 2694-7161

www.ejobsat.com

\begin{abstract}
This paper identifies the relationship between changes in oil prices and the returns of the world's highest-producing oil companies. Oil companies are divided into state-owned (national) and private companies. This paper focused on three different time periods to identify the relationship between changes in oil price and stock market returns by examining the specific backgrounds of each period. The results revealed that during oil's bearish market, it was more beneficial for investors to prefer state-owned companies to optimise their portfolios. The risk analysis focused on systematic risk, and the beta coefficients confirmed that state-owned companies are less sensitive to market shocks. State-owned companies are supported by governments during periods of downtrends in oil prices; therefore, they are less likely to go bankrupt. However, these companies do not have as much flexibility as private companies to cut their costs; therefore, they are more negatively affected by market movements not defined by shocks.
\end{abstract}

\section{KEY WORDS}

oil shock, stock markets, state-owned companies

\section{JEL CODES}

G12, G15, Q02

\section{INTRODUCTION}

The impact of oil price fluctuations on both the economy and the stock market returns has attracted the attention of politicians and economists alike (Alqattan and Alhayky, 2016). Individual stock prices in the oil and gas industry co-vary with oil price fluctuations
(Higson et al., 2004). A lot of research has been conducted on the relationship between oil prices and the stock prices of oil mining companies (Alhayki, 2014; Arouri and Rault, 2012; Abdalla, 2013).The rising price of oil price increases total costs in most industries (Rogers, 
2008). This is reflected in falling profits and, with regard to stocks, whose value is estimated by investors based on future profit, their value drops. Refining companies are forced to adapt to the volatility in oil prices by inveting new technologies, which in turn affect oil prices (Hefner, 2014). This demonstrates the bi-causal relationship between oil prices and the returns of oil mining companies (Dhaoui and Khraief, 2014). There is evidence that oil prices impact stocks in both developed (Dhaoui and Khraief, 2014) and developing countries (Basher and Sadorsky, 2006).

However, the type and strength of the influence of oil on the price of oil mining stocks also depends on the level of a country's development (Shaharudin et al., 2009); developing countries are not as technologically advanced, thus they are more sensitive to fluctuations in oil prices. A study conducted by Zakaria (2005) revealed that the relationship is also affected by ownership structure. Private companies are more strictly managed; therefore, they can adapt faster during crises. These companies also develop new technologies and cut their costs. However, state-owned companies are less likely to default because they are supported by governments when shocks on the oil market occur (Gutiérrez et al., 2021). These studies have not examined the details of oil price development. The differences in the impact of oil prices on private and state-owned companies should be studied in more detail, with a focus on trends in oil prices. This would help those investing in oil mining companies' stocks to rebalance their portfolios according to oil price development and with respect to market cycle sensitivity.

This paper makes three main contributions. First, it identifies the differences in the impact of oil price changes between private and stateowned companies. Second, it defines the relationship between oil prices and oil mining stock returns for separate trends in oil prices. The evidence suggests that this relationship varies according to the characteristics of the period, and that individual factors can also have an influence. Third, and most importantly, it offers concrete investment recommendations.

The paper is structured as follows: Section 2 is the literature review, Section 3 provides a detailed overview of the methodology and data used, the Granger causality results are presented in Section 4, Section 5 confirms the results of the robustness analysis and Section 6 presents the conclusion.

\section{LITERATURE REVIEW}

Since 1965, global crude oil consumption has risen from $30 \mathrm{mil}$. bbl/day to $90 \mathrm{mil}$. bbl/day. Developing economies have raised the standard of living of their inhabitants as a result of the extraction and consumption of traditional hydrocarbons. Economic dependence on crude oil is indicated by the trends in oil market prices. Crude oil transfers wealth from oil-importing countries (the United States, China, and India) to oil-exporting countries (Saudi Arabia, Russian Federation). Global energy consumption growth averaged $1.7 \%$ p.a. from 2010 to 2020 , with growth expected to decelerate gently beyond 2020. Non-OECD energy consumption will be $68 \%$ higher by 2030 , averaging $2.6 \%$ p.a. from 2010, and it accounts for $93 \%$ of global energy growth. The fastest-growing fuels are renewable fuels, including biofuels, which are expected to grow at $8.2 \%$ p.a. $2010-2030$ (BP, 2018). With gas selling at the equivalent of less than 25 USD/barrel of oil, and oil selling at approximately 100 USD/barrel, companies began applying the technologies they had successfully developed for gas extraction to extract oil from shale formations with low permeability, known in the industry as 'tight' reservoirs. The results were similarly impressive, and the United States is now the world's largest oil producer (International Energy Agency, 2021).

Current studies (Cuñado and Pérez de Gracia, 2005; Jiménez-Rodríguez and Sánchez, 2005) have emphasised the influence of oil prices on variables, such as rates of inflation, and interest, GDP and unemployment. A relationship 
between oil prices and stock price returns has been identified in emerging markets. Basher and Sadorsky (2006) identified the impact of oil price changes on 21 emerging stock market returns. They revealed that oil price shocks have a significant impact on stock price returns in emerging markets. There is an inherent risk on emerging stock markets when oil prices change and there is a relationship between this risk and other risks, such as total and market risks (Alqattan and Alhayky, 2016). Other studies have focused on the relationship (long or short-term) between the reactions of the Gulf Cooperation Council stock market (Bahrain, Kuwait, Saudi Arabia, Qatar, Oman, UAE) and the changes in oil prices (Alhayki, 2014; Arouri et al., 2010; Arouri and Rault, 2012; Onour, 2007). Gulf equity markets receive volatility from the oil market, but stock market volatility only spills over into the oil market in the case of Saudi Arabia (Malik and Hammoudeh, 2007). An increase in oil prices leads to higher stock market return volatility (Abdalla, 2013).

Oil price volatility and stock price fluctuations in emerging markets have two different negative ramifications on a company's profitability (Masih et al., 2011). First, there is a direct negative impact as production costs increase. increase. Second, there is an indirect negative effect as investors foresee the decline in a company's profit margins and make decisions that affect the stock market indices.

Cong et al. (2008) monitored the relationship between oil prices and the Chinese stock market, considering several variables, including short-term rate of return, industrial production, oil price, consumer price index, and return on stock. The authors did not find any statistically significant effect on the return on stock, or any evidence of asymmetric effects caused by increased oil price volatility. Moreover, a strong negative relationship between oil prices and stock market returns has been identified in seven developed countries (Dhaoui and Khraief, 2014). Hasan and Mahbobi (2013) used the Granger causality test to show that the impact of oil prices on the Toronto stock exchange has been more significant than it was years ago (their research covered the period from January 1990 to August 2011). Another study concluded that the changes in the stock price of 96 American oil extraction companies correlated positively with changes in both oil prices and the entire stock market (Scholtens and Wang, 2008). Another highlighted how companies that are more engaged in oil refining and the sale of refined products (downstream) may profit from price fluctuations while companies that extract only (upstream) tend to lose their value (Lis et al., 2012). One of the most recent studies into the influence of oil prices on the share prices of oil companies was conducted by Garcia (2016). The sample consisted of 26 global oil producing companies divided into three groups: mining, refining, and mining, and refining. The development of stock prices for refining companies could be used as a leading indicator for further changes in oil prices. The study also highlighted that additional leading indicators could be identified in the future.

The relationship between oil prices and oil stock prices has been identified by several studies; however, there are several aspects that are worthy of further research. Research conducted by Shaharudin et al. (2009) has shown that there are different dissimilarities according to the level of a country's development. When the emphasis is put to on dividing countries into from developed, emerging or semi-developed or semi-emerging countries, there are interesting results when profitability is compared by stateowned and private companies' stocks. Zakaria (2005) found similar results, concluding that private companies are more adaptable; however, the author did not study the relationship with a focus on different oil price trends. It is known that state-owned companies are less flexible because they did not optimise their wells due to oil price volatility and they were not as motivated to innovate as private companies (Hefner, 2014). However, a recent study by Gutiérrez et al. (2021) found that state-owned companies are not as sensitive to oil shocks as states do not manage these companies effectively; therefore, even if they suffer from economic problems, governments fund them. This aspect of the dissimilarities between stateowned and private oil mining companies should be analysed in more detail, with a focus on specific oil trends. 


\section{METHODOLOGY AND DATA}

The dataset for this study included data from six companies and two indices. Daily data of returns, including dividend reinvestment, covering 19 years was used. The entire time period is subdivided into three subperiods representing structural breaks in oil price trends. The first subperiod was from $01 / 2002$ to $07 / 2008$, representing a period of stable price rises. The second subperiod was from $08 / 2008$ to $07 / 2014$, characterised by the steepest oil price drop, followed by rising prices for two years and then three years of increasing volatility. The oil price was in range from the beginning of the period. The third period is from $08 / 2014$ to $10 / 2021$, representing the downtrend in oil prices. The oil price and its development utilised were expressed by the West Texas Intermediate Cushing (WTI) as it is the main benchmark used to evaluate crude oil (Fattouh, 2011).

BP, ExxonMobil (XOM) and Lukoil (LUK) were chosen as representatives of private companies and PetroChina (PTR), Equinor (EQNR), and Petrobras (PBR) as representatives of state-owned companies. These companies were chosen to compare the impact of oil shocks on private and state-owned companies separately. Although Lukoil is a private company there are some concerns about the independence of Lukoil. Therefore Lukoil may have more similarities with state-owned companies (Gorst, 2007). Such a company would be good for the validation of results. Another criterion for choosing these companies was that they are listed on the same stock exchange. All of these companies are oil miners and they represent both developed and developing countries. Both their market capitalisation and share of the global market were considered (see Tab. 1 and 2).

The analyses included two indices to check and assess the results. The first was the ARCA Oil \& Gas Index (ticker XOI), which represents and averages the oil companies' stock prices, and the second was the S\&P 500 Index. Both indices are used for risk analysis. The data was transformed by logarithmic difference.
Tab. 1: Selected oil companies

\begin{tabular}{lcc}
\hline Private companies & Revenue & Market cap. \\
\hline BP & 303.73 & 90.40 \\
ExxonMobil & 290.20 & 268.46 \\
Lukoil & 127.70 & 58.74 \\
PetroChina & 392.90 & 139.95 \\
Equinor & 79.60 & 85.42 \\
Petrobras & 95.60 & 73.50 \\
\hline
\end{tabular}

Note: Revenue is in billion USD; Market cap. shows estimated market capitalisation in billion USD.

Source: Yahoo Finance (2021b, 2021d, 2021e, 2021f, 2021g, 2021h).

One of the characteristics observed by various authors is that reactions to oil prices are not solely dependent on contemporary oil price changes since it has been proven that lagged prices also possess explanatory power (Sill, 2007). Although there may be a strong correlation between the variables considered, it does not necessarily mean causation between them. Consequently, the Granger causality test was conducted at the end to demonstrate the dependence or independence between the trends in oil price, measured by the WTI price development and the stock prices of the oil companies.

To demonstrate causal dependencies, two regression equations were used (Mahdavi and Sohrabian, 1991):

$$
\begin{aligned}
\operatorname{STOCK}_{t}= & a_{1}+\sum_{i=1}^{m} \beta_{i}(\mathrm{STOCK})_{t-i}+ \\
& +\sum_{j=1}^{m} \gamma_{j}(\mathrm{WTI})_{t-1}+e_{t} \\
\mathrm{WTI}_{t}=a_{1} & +\sum_{i=1}^{m} \gamma_{i}(\mathrm{WTI})_{t-i}+ \\
& +\sum_{j=1}^{m} \beta_{j},(\mathrm{STOCK})_{t-j}+e_{t}
\end{aligned}
$$

where STOCK represents the stock price of selected oil companies, WTI represents WTI oil prices, $\gamma$ and $\beta$ are the regression coefficients of the equation, $e_{t}$ is a random error, and $i, j$ is a lag ( $m$ is the maximum order of lag). 
Tab. 2: Selected companies

\begin{tabular}{lllcr}
\hline Company & Shareholders & Country & Oil production & Ranking in world's production \\
\hline BP & $<1 \%$ state & UK & 1.99 & 9 \\
ExxonMobil & $<6 \%$ state & US & 2.35 & 2 \\
Lukoil & $50 \%$ management & Russia & 1.64 & 18 \\
PetroChina & $86 \%$ state & China & 2.45 & 5 \\
Equinor & $67 \%$ state & Norway & 2.07 & 11 \\
Petrobras & $50 \%$ state & Brazil & 1.99 & 16 \\
\hline
\end{tabular}

Note: Shareholders states the shareholder with higher share; production is in thousand bbl/day; ranking shows the position of the country in the oil production by country rankings. Source: Yahoo Finance (2021b, 2021d, 2021e, 2021f, $2021 \mathrm{~g}, 2021 \mathrm{~h}$ ).

During the monitored period (from 01/2002 to $10 / 2021$ ), two situations significantly affected oil prices: the financial crisis of 2008 and the expansion into unconventional supplies followed by a shift in OPEC's policy in 2014. These structural breaks were identified by the Chow test (Brooks, 2008). The first equation expressed that the current stock price was set by both past oil prices and the past prices of the stocks under review while the second equation identified whether the current oil price was determined by past stock prices, i.e. previous oil prices.

\section{RESULTS}

The analysis of the relationship between oil prices and the stock development of oil companies - companies extracting and processing crude oil - was conducted using a sample of six companies, three state-owned and three private.

In the selected time period (the past 19 years), crude oil has shown increased volatility, with oil prices ranging from a low of $8 \mathrm{USD} / \mathrm{bbl}$. to a high of $140 \mathrm{USD} / \mathrm{bbl}$. The market had to cope with the Iraq war, and price slumps that correlated with the drop in the financial markets, before experiencing a post-war twist in the form of steady growth and stable periods, which ended in a drop caused by excess supply over demand.

The reserve and production positions of national oil companies may be cause for concern if they operated similarly to the private international oil companies, and state ownership was simply a matter of how the stock shares of the company were held (Pirog, 2007). However, it is likely that the objectives of many national oil companies, as well as the characteristics of their operations, differ across companies in the oil industry. Tab. 2 shows the companies according to the country in which their stocks are issued, their ownership and their ranking on the oil production by country ranking.

The paper aimed to determine the interdependence of oil prices and stock prices of oilextraction companies, which will help both in making investment decisions and in determining whether the companies' stock prices react differently to trends in oil prices depending on whether a government has a stake or the company is private.

The selected benchmarks were the ARCA Oil \& Gas Index and the S\&P 500 Index. The ARCA Oil \& Gas Index is used to track the development of the oil industry through the price changes of oil companies dealing with extraction, refining and development. According to internal regulations, companies listed in the index can change; currently, the index comprises 21 companies, five of which were examined in this study (all except for Lukoil).

The S\&P 500 Index is considered to be the best indicator of the stock trends of the largest US companies. The energy sector in the index covers $6.3 \%$ of the value, and only ExxonMobil was included in the sample of companies used in this study. 


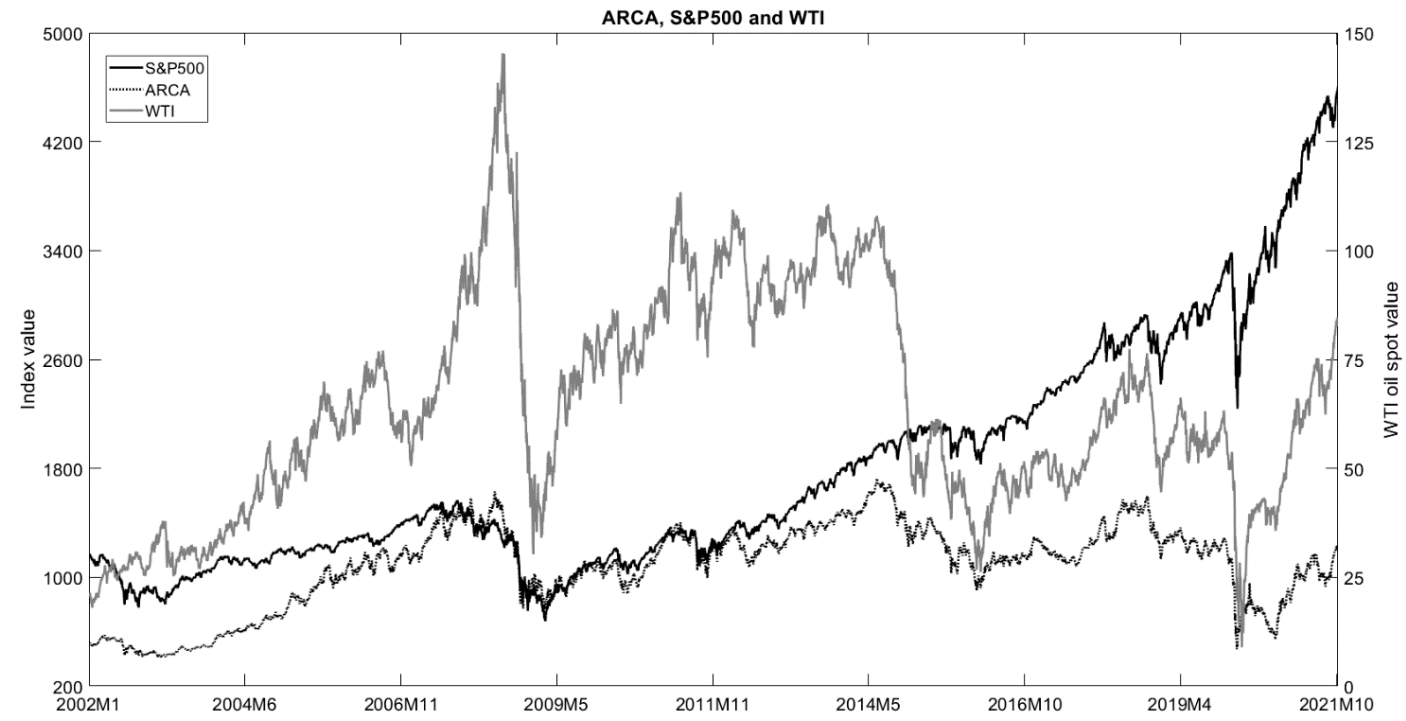

Fig. 1: Oil price and stock/oil index development. Source: Yahoo Finance (2021a, 2021c, 2021i)

Tab. 3: Granger causality, entire period

\begin{tabular}{lc}
\hline Causality & F-statistics \\
\hline $\mathrm{PTR} \longrightarrow \mathrm{WTI}$ & $2.80^{* *}$ \\
$\mathrm{WTI} \longrightarrow \mathrm{PTR}$ & $2.11^{*}$ \\
$\mathrm{EQNR} \longrightarrow \mathrm{WTI}$ & $3.50^{* * *}$ \\
$\mathrm{WTI} \longrightarrow \mathrm{EQNR}$ & $14.53^{* * *}$ \\
$\mathrm{~S} \& \mathrm{P} 500 \longrightarrow \mathrm{WTI}$ & $2.64^{* *}$ \\
$\mathrm{WTI} \longrightarrow \mathrm{S} \& \mathrm{P} 500$ & $2.69^{* *}$ \\
$\mathrm{BP} \longrightarrow \mathrm{WTI}$ & $7.65^{* * *}$ \\
$\mathrm{WTI} \longrightarrow \mathrm{BP}$ & $3.55^{* * *}$ \\
$\mathrm{XOM} \longrightarrow \mathrm{WTI}$ & $4.60^{* * *}$ \\
$\mathrm{WTI} \longrightarrow \mathrm{XOM}$ & $3.78^{* * *}$ \\
$\mathrm{LUK} \longrightarrow \mathrm{WTI}$ & $2.85^{* * *}$ \\
$\mathrm{WTI} \longrightarrow \mathrm{LUK}$ & $2.49^{* * *}$ \\
$\mathrm{PBR} \longrightarrow \mathrm{WTI}$ & $2.93^{* *}$ \\
$\mathrm{WTI} \longrightarrow \mathrm{PBR}$ & $3.15^{* * *}$ \\
$\mathrm{ARCA} \longrightarrow \mathrm{WTI}$ & $7.40^{* * *}$ \\
$\mathrm{WTI} \longrightarrow \mathrm{ARCA}$ & $2.74^{* * *}$ \\
\hline
\end{tabular}

Note: The calculations show a Granger causality test of the relationship between WTI oil returns and selected oil-producing company stock returns in the VAR model during the entire period. The F-based Wald test statistics indicate the rejection of the null hypothesis; that there was no causal relationship (WTI returns affect selected stock returns or vice versa) in the VAR model. The significance at the $10 \%$ level is denoted by *, $5 \%$ level by ** and $1 \%$ level by ***. The companies are presented by their tickers.
As shown in Fig. 1, before the 2008 financial crisis the S\&P 500 and WTI indices loosely followed each other, but began to move in opposition during the record-high oil prices in the summer of 2008. However, since January 2009, both measures have followed each other in near lockstep, breaking only in the months surrounding the Arab Spring uprisings after another price spike.

The interdependence between the oil price trends and the stock price of the oil extraction companies was analysed first over the whole time period. The relationship between stocks and oil prices was found to be volatile, with the correlation between the returns of stocks and oil swinging between positive and negative values. In other words, the stock and oil prices sometimes moved in the same direction, and sometimes in opposite directions (Bernanke, 2016).

As is evident from Tab.3, there was a bi-causal relationship for almost all selected companies. The stock prices of the oil-producing companies were not only affected by oil prices but they also affected the oil prices. A slightly less significant causality could be found for state-owned companies. The interpretation of this result was in accordance with Gutiérrez et al. (2021), who stated that state-owned 
Tab. 4: Systemic risk (beta) of private companies

\begin{tabular}{ccccccc}
\hline & \multicolumn{2}{c}{ LUK to } & \multicolumn{2}{c}{ XOM to } & \multicolumn{2}{c}{ BP to } \\
Period & S\&P 500 & ARCA & S\&P 500 & ARCA & S\&P 500 & ARCA \\
\hline 1. & 0.16 & 0.26 & 0.49 & 0.83 & 0.42 & 0.80 \\
2. & 0.30 & 0.42 & 0.73 & 1.04 & 0.50 & 0.76 \\
3. & 0.23 & 0.54 & 0.42 & 1.02 & 0.32 & 0.85 \\
EP & 0.25 & 0.41 & 0.54 & 0.98 & 0.41 & 0.81 \\
\hline
\end{tabular}

Note: The table presents the beta coefficients to the S\&P 500 and ARCA indices; EP means entire period.

The companies are presented by their tickers.

Tab. 5: Systemic risk (beta) of state-owned companies

\begin{tabular}{ccccccc}
\hline & \multicolumn{2}{c}{ PTR to } & \multicolumn{2}{c}{ ENQR to } & \multicolumn{2}{c}{ PBR to } \\
Period & S\&P 500 & ARCA & S\&P 500 & ARCA & S\&P 500 & ARCA \\
\hline 1. & 0.20 & 0.30 & 0.09 & 0.25 & 0.18 & 0.30 \\
2. & 0.48 & 0.64 & 0.37 & 0.59 & 0.34 & 0.49 \\
3. & 0.28 & 0.65 & 0.21 & 0.61 & 0.15 & 0.34 \\
EP & 0.33 & 0.53 & 0.22 & 0.49 & 0.21 & 0.38 \\
\hline
\end{tabular}

Note: The table presents the beta coefficients to the S\&P 500 and ARCA indices; EP means entire period.

The companies are presented by their tickers.

companies might be less sensitive to market shocks as, when shocks appear on the market, they are better supported by governments and therefore are not so cycle sensitive. As other companies potentially go bankrupt, the state gives additional funds to these companies to protect them, even if this may not be economically effective.

Hasan and Mahbobi (2013) found the same results in their study on the Canadian market. However, these findings have to be validated by looking at the beta coefficients concerning market sensitivity, as well as at the subperiods separately, in the context of structural breaks in oil prices.

In order to obtain results that could be applied across the entire oil industry, the following parameters of the analysed companies with/without public shares would have to be met: (1) The geopolitical conditions must be identical. This can only be ensured for companies from a single region. as there are drawbacks to comparing companies that produce or extract oil in regions/areas or in the area near to certain conflicts or in risky countries to companies that do not; (2) There must be similar political systems in the producer countries, see Zakaria (2005); (3) There also should be differences between the majority and minority stockholders and their interests (Zakaria, 2005); (4) There should be similar levels of oil extraction; however, each company different other costs for mining. For example, companies' oil jacks' are located in remote permafrost landscapes, mining from very deep wells but with extreme climatic conditions. In contrast, the Arabic companies extract oil from shallow wells in inaccessible areas. Therefore, according to Statista (2018), the cost for extracting one barrel of oil in 2015 Kuwait was approximately 8.5 USD, approximately 9.9 USD in Saudi Arabia and approximately 17.2 USD in the Russian Federation. Thus, if the price of oil begins to decrease, companies will begin to close these extremely costly wells and focus their business on other activities, such as the production of natural gas; (5) There should be similar levels of integration, i.e. when conducting comparisons with companies that extract/buy oil and then carry out refining operations, the focus should not be solely on extraction and subsequent sales.

Tab. 4 and 5 show the beta coefficients calculated for all companies. These companies displayed different sensitivities to market and oil prices during different time periods. 
From the viewpoint of systematic risk (the beta), the state-owned companies appeared to be less risky than the private companies over the entire monitored period.

The level of systematic risk was lower for the state-owned companies even if they conducted mining activities in developing countries that are associated with being a higher risk. The state-owned companies had very different betacoefficients, mainly during the third period, which was characterised by a downtrend in oil prices. This can be explained by the fact that private companies are more business oriented; therefore, they are also more cyclical. However, state-owned companies are supported by their states, even if this is not economically efficient. Therefore, these companies' stocks are less affected in periods of oil price downtrends (Gutiérrez et al., 2021). Interesting results could be seen for the private Russian company Lukoil, which may act more like a state-owned company because of the control the Russian government exercises (Ediger et al., 2021). The impact was calculated using the S\&P 500 Index and the ARCA Index. Due to the higher diversification of the S\&P 500 Index, a lower beta was found. However, if the focus was on the risk profile (the beta), investors should expect higher profits.

\subsection{Robustness Check}

As was the case for the simple correlation, the Granger causality test was also performed for the subperiods. These subperiods were defined by the Chow test and represent three trends in oil prices. The period from 2002 to 2008 represents oil uptrend, the period from 2008 to 2014 represents a period when oil prices were in the same range as the beginning of the period. The third period is defined by an oil price downtrend as the highest value of oil was achieved at the beginning of the period. However, when analysing the subperiods, the results were different than those for the entire period under review even if the same lag duration was applied (see Tab. 6).

The first period (2002-2008) is characterised by a weak correlation between oil and stock prices. When the comparing coefficients of individual stocks, the low correlation rate was even more pronounced. Similar results appeared in a study by Norland (2017), which states that pre-2009, the correlation was close to zero and, at times, negative. Similar results were reported by Nguyen and Bhatti (2012), who found that the Chinese market was not affected by oil prices from 2000 to 2009. This can be explained by the tranquil period in the stock markets, steadily rising oil prices and GDP, and the general independence of stock markets from oil prices (as shown by the value of the S\&P 500).

Tab. 6: Granger causality, subperiods, F-statistics

\begin{tabular}{|c|c|c|c|}
\hline Casuality & $\begin{array}{c}01 / 2002 \text { to } \\
07 / 2008\end{array}$ & $\begin{array}{c}08 / 2008 \text { to } \\
07 / 2014\end{array}$ & $\begin{array}{c}08 / 2014 \text { to } \\
10 / 2021\end{array}$ \\
\hline $\mathrm{PTR} \longrightarrow \mathrm{WTI}$ & 0.61 & $6.90^{* * *}$ & 1.29 \\
\hline $\mathrm{WTI} \longrightarrow \mathrm{PTR}$ & 0.35 & $3.48^{* * *}$ & 0.82 \\
\hline $\mathrm{EQNR} \longrightarrow \mathrm{WTI}$ & 0.11 & $1.92^{* *}$ & $4.40^{* * *}$ \\
\hline $\mathrm{WTI} \longrightarrow \mathrm{EQNR}$ & $66.75^{* * *}$ & $6.87^{* * *}$ & $5.43^{* * *}$ \\
\hline $\mathrm{PBR} \longrightarrow \mathrm{WTI}$ & $4.46^{* *}$ & $9.66^{* * *}$ & 0.67 \\
\hline $\mathrm{WTI} \longrightarrow \mathrm{PBR}$ & 0.18 & $5.19^{* * *}$ & $2.31^{*}$ \\
\hline $\mathrm{XOM} \longrightarrow \mathrm{WTI}$ & $5.29^{* *}$ & $4.38 * * *$ & $6.21^{* * *}$ \\
\hline $\mathrm{WTI} \longrightarrow \mathrm{XOM}$ & 0.24 & $4.55^{* * *}$ & $2.44^{* * *}$ \\
\hline $\mathrm{LUK} \longrightarrow \mathrm{WTI}$ & 1.04 & $6.17^{* * *}$ & $5.43^{* * *}$ \\
\hline $\mathrm{WTI} \longrightarrow \mathrm{LUK}$ & 0.24 & $5.41^{* * *}$ & 1.19 \\
\hline $\mathrm{BP} \longrightarrow \mathrm{WTI}$ & 1.69 & $1.93^{*}$ & $7.85^{* * *}$ \\
\hline $\mathrm{WTI} \longrightarrow \mathrm{BP}$ & 2.41 & $2.77^{* *}$ & $2.62^{* * *}$ \\
\hline
\end{tabular}

Note: The calculations show a Granger causality test of the relationship between WTI oil returns and selected oil-producing company stock returns in the VAR model during the chosen subperiod. The F-based Wald test statistics indicate the rejection of the null hypothesis; that there was no causal relationship (WTI returns affect selected stock returns or vice versa) in the VAR model. The significance at the $10 \%$ level is denoted by *, $5 \%$ level by **, and $1 \%$ level by $* * *$. The companies are presented by their tickers.

For the second period, the S\&P 500 Index and the oil price began to correlate This can be explained by the period of the Great Recession, which saw an unprecedented and sustained fall in oil prices, a significant decrease in oil marketspecific demand shocks and the collapse of the financial markets, i.e. a clear co-movement in the same direction (Broadstock and Fillis, 2014). Another plausible explanation for this positive relationship between the oil marketspecific shocks and stock market returns can be interpreted in agreement with the fact, that 
apart from uncertainty regarding the future availability of oil, financial speculation in the oil market also drove oil-market specific shocks (Kilian and Lee, 2014; Kilian and Murphy, 2014).

From 2009, the co-movement increased. It was affected by the ongoing quantitative easing by purchasing trillions of USD worth of (default) risk-free assets, such as government bonds, and low-risk assets, such as AAA-rated mortgage-backed securities. Additionally, the Federal Reserve would force investors into risky assets, such as stocks (Norland, 2017). QE also squeezed capital out of the US and redirected it to emerging markets, which increased demand for all commodities, including oil.

The relationship stayed at a similar level during the third period (2014-2021). It was later characterised by stable oil prices without fluctuations, and the levels of the correlation coefficients between all companies and the ARCA index were at all-time high. Although the dependence of the oil extraction companies' stock prices and the oil price trends was confirmed, the causal dependence and its direction must be verified using Granger causality. The Granger causality test was provided by using Formula (2).

When the oil price rose, the profitability of state-owned companies was higher than at the time of fall prices. During the third period, Petrobras generated a significant profit of $428.9 \%$ p.a. This was due to a loan from the China Development Bank of up to 10 billion USD to pay nearly all its 12 bil. USD in maturing obligations in 2016. In the second period, when the oil price was stable, and all other companies realised a profit of approximately $20 \%$ p.a., Petrobras made a loss of $14 \%$ p.a. There were several reasons for this, including a large-scale price-fixing, bribery and political kick-back scandal. It led to record Petrobras losses and write-downs in 2014 and related arrests continue to be made in Brazil and abroad. Additionally, its formerly investmentgrade debt rating has been downgraded to junk status as a result, limiting its access to capital markets and increasing finance costs.

The overall results of robustness check reveal that the state companies show lower comovement with oil prices; it was in agreement with the results for the entire period. Additionally, more state-owned companies were affected by oil prices during the oil price uptrend. The second period was quite similar for both private and state-owned companies. However, interesting differences could be seen for the third period, the oil downtrend. Most of the selected private companies had bi-causal relationship with oil prices, while state-owned companies were not as affected by falling oil prices. This could be explained by the fact that the state-owned companies are less sensitive during oil drops as they are better supported by the state, which was in line with Gutiérrez et al. (2021). Interesting is also the fact that the WTI didn't have an impact on Lukoil during the third subperiod what is dissimilarity with other private companies. The reason of it provides Gorst (2007) who identified the impact of the state in Russia on private companies also. This finding contributes to our robustness analysis.

\section{DISCUSSION AND CONCLUSIONS}

Based on oil price trends over selected time periods, it is advisable to consider investing in stocks of oil companies according to their ownership structure. State-owned companies are less motivated to cut their costs or invest in new technologies. This statement was confirmed by the analysis conducted in this study, which identified private-companies as having more significant bi-causal relationships with oil prices.
However, this bi-causal relationship was more significant during periods of oil price downtrends. Analyses focusing on each period were more informative and will enable investors to make a better assessment as to what action is best suited to their needs. This paper provided evidence that state-owned companies are less sensitive to oil cycles and, as oil prices drop, they are supported by governments. Private 
companies are managed more effectively from an economic point of view. Due to the support given by states during oil price shocks, the stock returns of state-owned companies are less risky to hold (Gutiérrez et al., 2021). Another piece of evidence is a private company Lukoil, which has reported results similar to the state-owned companies because of more strict state control (Ediger et al., 2021). Because of the loyalty to the state (Gorst, 2007), the Lukoil company was less influenced by oil price downtrends.

A limiting factor in assessing the influence of state-owned companies on the development and response of their stocks was the dissimilarity of these companies. When the oil price was stable, the profitability of the state-owned companies was very similar to the private companies. Investors must also consider that the profit of state-owned companies does not need to be reinvested by the company in new technologies for example.

In summary, it can be concluded that there are differences between the stock returns of state-owned and private companies, which is manifested mainly according to oil price trends. Therefore, investors are recommended to hold more state-owned oil stocks during oil price decreases.

\section{ACKNOWLEDGEMENT}

This outcome was supported by the Internal Grant Schemes of Mendel University in Brno, registration no. CZ.02.2.69/0.0/0.0/19_073/0016670, funded by the ESF.

\section{REFERENCES}

AbDalla, S. Z. S. 2013. Modelling the Impact of Oil Price Fluctuations on the Stock Returns in an Emerging Market: The Case of Saudi Arabia. Interdisciplinary Journal of Research in Business, 2 (10), 10-20. ISSN 2046-7141.

Alhayki, Z. J. 2014. The Dynamic Co-Movements between Oil and Stock Market Returns in the Case of GCC Countries. Journal of Applied Finance \& Banking, 4 (3), 103-113.

Alqattan, A. A. and Alhayky, A. 2016. Impact of Oil Prices on Stock Markets: Evidence from Gulf Cooperation Council (GCC) Financial Markets. Amity Journal of Finance, 1 (1), 1-8. ISSN 2455-9741.

Arouri, M. E. H., Lahiani, A. and Bellalah, M. 2010. Oil Price Shocks and Stock Market Returns in Oil-Exporting Countries: The Case of GCC Countries. International Journal of Economics and Finance, 2 (5), 132-139. DOI: $10.5539 /$ ijef.v2n5p132.

Arouri, M. E. H. and Rault, C. 2012. Oil Prices and Stock Markets in GCC Countries: Empirical Evidence from Panel Analysis. International Journal of Finance 83 Economics, 17 (3), 242-253. DOI: $10.1002 /$ ijfe.443.

BAsher, S. A. and SAdorsky, P. 2006. Oil Price Risk and Emerging Stock Markets. Global Finance Journal, 17 (2), 224-251. DOI: 10.1016/j.gfj.2006.04.001.
Bernanke, B. 2016. The Relationship Between Stocks and Oil Price. Brookings [online]. Available at: http://www . brookings. edu/blog/ben-bernanke /2016/02/19/the-relationship-between-stocks -and-oil-prices/.

BP. 2018. Energy Outlook [online]. Available at: https://www.bp.com/content/dam/ bp/en/corporate/pdf/energy-economics/ energy-outlook/bp-energy-outlook-2018.pdf.

Broadstock, D. C. and Filis, G. 2014. Oil Price Shocks and Stock Market Returns: New Evidence from the United States and China. Journal of International Financial Markets, Institutions and Money, 33 (C), 417-433. DOI: $10.1016 /$ j.intfin.2014.09.007.

Brooks, C. H. 2008. Introductory Econometrics for Finance. Cambridge University Press. ISBN 978-0-521-69468-1.

Cong, R.-G., Wei, Y.-M., JiaO, J.-L. and FAN, Y. 2008. Relationships between Oil Price Shocks and Stock Market: An Empirical Analysis from China. Energy Policy, 36 (9), 3544-3553. DOI: 10.1016/j.enpol.2008.06.006.

Cuñado, J. and Pérez de Gracia, F. 2005. Oil Prices, Economic Activity, and Inflation: Evidence for Some Asian Economies. The Quarterly Review of Economics and Finance, 45 (1), 65-83. DOI: $10.1016 /$ j.qref.2004.02.003. 
Dhaoui, A. and Khraief, N. 2014. Empirical Linkage between Oil Price and Stock Market Returns and Volatility: Evidence from International Developed Markets [online]. Economics Discussion Paper No. 2014-12. Kiel Institute for the World Economy. Available at: http://www.economics-ejournal. org/economics/discussionpapers/2014-12.

Ediger, V. Ş., Bowlus, J. V. and Dursun, A. F. 2021. State Capitalism and Hydrocarbon Security in China and Russia. Energy Strategy Reviews, 38, 100725. DOI: 10.1016/j.esr.2021.100725.

Fattoun, B. 2011. An Anatomy of the Crude Oil Pricing System. Working Paper. The Oxford Institute for Energy Studies. ISBN 978-1-907555-20-6.

Garcia, J. P. 2016. Financial Performance in Upstream, Downstream, and Integrated Oil Companies in Response to Oil Price Volatility. Finance Undergraduate Honors Theses, 34 [online]. Available at: https://scholarworks . uark. edu/finnuht/34.

Gorst, I. 2007. Lukoil: Russia's Largest Oil Company [online]. James A. Baker III Institute for Public Policy. Available at: https://www.bakerinstitute.org/media/files/ page/993b42c4/noc_lukoil_gorst.pdf.

Gutiérrez, D. S., Paz, M. J. and Vite, A. M. 2021. Factors That Explain the Results of the National Oil Companies: The Impact of the Fiscal Role on Pemex's Results. Resources Policy, 74, 102280. DOI: $10.1016 /$ j.resourpol.2021.102280.

Hasan, S. and Mahbobi, M. 2013. The Increasing Influence of Oil Prices on the Canadian Stock Market. The International Journal of Business and Finance Research, 7 (3), 27-39.

Hefner, R. A. 2014. The United States of Gas: Why the Shale Revolution Could Have Happened Only in America. Foreign Affairs, 93 (3), 9-14.

Higson, C., Holly, S., Kattuman, P. and Platis, S. 2004. The Business Cycle, Macroeconomic Shocks, and the Cross-Section: The Growth of UK Quoted Companies. Economica, 71 (282), 299-318.

International Energy Agency. 2021. Crude Oil Production (EJ). Atlas of Energy [online]. Available at: http://energyatlas.iea.org/\#! /tellmap/-1920537974.

Jiménez-Rodríguez, R. and SÁnchez, M. 2005. Oil Price Shocks and Real GDP Growth: Empirical Evidence for Some OECD Countries. Applied Economics, 37 (2), 201-228. DOI: $10.1080 / 0003684042000281561$.

KIlian, L. and LeE, T. K. 2014. Quantifying the Speculative Component in the Real Price of Oil: The Role of Global Oil Inventories. Journal of International Money and Finance, 42, 71-87. DOI: 10.1016/j.jimonfin.2013.08.005.
Kilian, L. and Murphy, D. P. 2014. The Role of Inventories and Speculative Trading in the Global Market for Crude Oil. Journal of Applied Econometrics, 29 (3), 454-478. DOI: $10.1002 /$ jae.2322.

Lis, B., Nessler, C. and Retzmann, J. 2012. Oil and Cars: The Impact of Crude Oil Prices on the Stock Returns of Automotive Companies. International Journal of Economics and Financial Issues, 2 (2), 190-200. ISSN 2146-4138.

Mahdavi, S. and Sohrabian, A. 1991. The Link Between the Rate of Growth of Stock Prices and the Rate of Growth of GNP in the United States: A Granger Causality Test. The American Economist, 35 (2), 41-48. DOI: 10.1177/056943459103500206.

Malik, F. and Hammoudeh, S. 2007. Shock and Volatility Transmission in the Oil, US and Gulf Equity Markets. International Review of Economics \& Finance, 16 (3), 357-368. DOI: $10.1016 /$ j.iref.2005.05.005.

Masih, R., Peters, S. and De Mello, L. 2011. Oil Price Volatility and Stock Price Fluctuations in an Emerging Market: Evidence from South Korea. Energy Economics, 33 (5), 975-986. DOI: $10.1016 /$ j.eneco.2011.03.015.

Nguyen, C. C. and Bhatti, M. I. 2012. Copula Model Dependency Between Oil Prices and Stock Markets: Evidence from China and Vietnam. Journal of International Financial Markets, Institutions and Money, 22 (4), 758-773. DOI: $10.1016 /$ j.intfin.2012.03.004.

Norland, E. 2017. Economics of Oil-Equity Correlations [online]. Available at: https:// www. cmegroup.com/education/files/why-are -equities-moving-in-tandem-with-oil.pdf.

Onour, I. A. 2007. Impact of Oil Price Volatility on Gulf Cooperation Council Markets' Return. OPEC Review, 31 (3), 171-189. DOI: $10.1111 /$ j.1468-0076.2007.00182.x.

Pirog, R. L. 2007. The Role of National Oil Companies in the International Oil Market [online]. CRS Report for Congress. Available at: https://pdfs.semanticscholar.org/e1c9/ 2675def6ea527370f9aaf 1cbe7441556e7cd.pdf.

Rogers, J. 2008. Žhavé komodity: Jak může kdokoliv investovat se ziskem na světových trzích. Praha: Grada. ISBN 978-80-247-2342-6.

Sill, K. 2007. The Macroeconomics of Oil Shocks. Business Review, Q1, 21-31.

Shaharudin, R., Samad, F. and Bhat, S. 2009. Performance and Volatility of Oil and Gas Stocks: A Comparative Study on Selected O\&G Companies. International Business Research, 2 (4), 87-99. DOI: 10.5539/ibr.v2n4p87.

Scholtens, B. and WAng, L. 2008. Oil Risk in Oil Stocks. The Energy Journal, 29 (1), 89-111. DOI: 10.5547/ISSN0195-6574-EJ-Vol29-No1-5. 
Statista. 2018. Average Price to Produce One Barrel of Oil in Top Oil Producing Countries Worldwide in 2015 [online]. Available at: http://www.statista. com/statistics/597669/cost-breakdown-of -producing-one-barrel-of-oil-in-the-worlds -leading-oil-producing-countries/.

Yahoo Finance. 2021a. Arca Oil Index [online]. Available at: https://finance.yahoo.com/quote/ $\% 5 \mathrm{EXOI} /$ history? $\mathrm{p}=\% 5 \mathrm{EXOI}$.

Yahoo Finance. 2021b. BP [online]. Available at: https: //finance. yahoo.com/quote/BP/history?p=BP.

Yahoo Finance. 2021c. Crude Oil [online]. Available at: https://finance.yahoo.com/quote/CL\%3DF/ history? $\mathrm{p}=\mathrm{CL} \% 3 \mathrm{DF}$.

Yahoo Finance. 2021d. Equinor ASA [online]. Available at: https://finance.yahoo.com/quote/EQNR. OL/ history?p=EQNR. OL.
Yahoo Finance. 2021e. Exxon Mobil

Corporation [online]. Available at: https:

//finance.yahoo.com/quote/XOM/history?p=XOM.

Yahoo Finance. 2021f. PJSC Lukoil [online]. Available at: https://finance.yahoo.com/quote/LUKOY/ history?p=LUKOY.

Yahoo Finance. 2021g. PetroChina [online]. Available at: https://finance.yahoo.com/quote/PTR/ history? $p=$ PTR.

Yahoo Finance. 2021h. Petróleo Brasileiro [online]. Available at: https://finance.yahoo.com/quote/ $\mathrm{PBR} /$ history? $\mathrm{p}=\mathrm{PBR}$.

Yahoo Finance. 2021i. S\&P 500 [online]. Available at: https: //finance. yahoo.com/quote/\%5EGSPC/ history? $\mathrm{p}=\% 5 \mathrm{EGSPC}$.

ZAKARIA, F. 2005. Budoucnost svobody: Neliberální demokracie v USA $i$ ve světě. Praha: Academia.

\section{ANNEX}

Tab. 7: Descriptive Statistics

\begin{tabular}{lrrrrrrrrrr}
\hline Variables & Obs. & \multicolumn{1}{c}{ Mean } & Std. Dev. & \multicolumn{1}{c}{ Min } & \multicolumn{1}{c}{$\mathbf{0 . 2 5}$} & \multicolumn{1}{c}{ Mdn } & $\mathbf{0 . 7 5}$ & Max & Skewness & Kurtosis \\
\hline S\&P500 & 4870 & 1789.40 & 848.28 & 676.53 & 910.45 & 1418.10 & 1925.75 & 4605.40 & 0.47 & 0.89 \\
ARCA & 4870 & 1082.80 & 309.78 & 411.09 & 951.82 & 11143.10 & 1334.38 & 1726.20 & -0.55 & -0.49 \\
WTI & 4870 & 64.21 & 24.62 & 8.91 & 42.42 & 60.81 & 79.21 & 145.31 & -0.39 & -0.51 \\
BP & 4870 & 26.72 & 5.54 & 14.27 & 22.37 & 26.37 & 30.38 & 39.82 & 0.02 & -0.58 \\
ExxonMobil & 4870 & 50.88 & 16.17 & 16.95 & 41.74 & 54.47 & 67.20 & 77.25 & -0.49 & -0.91 \\
Lukoil & 4870 & 39.86 & 20.15 & 6.32 & 28.31 & 38.51 & 48.71 & 106.94 & 0.59 & 0.26 \\
Equinor & 4870 & 98.59 & 41.76 & 24.60 & 71.49 & 93.82 & 116.15 & 235.71 & 0.42 & -0.02 \\
Petrobras & 4870 & 15.78 & 11.36 & 1.50 & 6.63 & 13.07 & 19.50 & 59.96 & 1.18 & 0.86 \\
PetroChina & 4870 & 62.14 & 28.59 & 8.36 & 40.00 & 62.19 & 84.37 & 164.18 & -0.08 & -0.63 \\
S\&P500. log dif & 4869 & 0.00 & 0.01 & -0.13 & -0.01 & 0.00 & 0.01 & 0.11 & -0.45 & 12.21 \\
ARCA. log dif & 4869 & 0.00 & 0.02 & -0.24 & -0.01 & 0.00 & 0.01 & 0.16 & -0.69 & 15.93 \\
WTI. log dif & 4869 & 0.00 & 0.03 & -0.72 & -0.01 & 0.00 & 0.01 & 0.43 & -2.08 & 91.63 \\
BP. log dif & 4869 & 0.00 & 0.02 & -0.21 & -0.01 & 0.00 & 0.01 & 0.20 & -0.50 & 14.97 \\
ExxonMobil. log dif & 4869 & 0.00 & 0.02 & -0.15 & -0.01 & 0.00 & 0.01 & 0.16 & -0.05 & 10.85 \\
Lukoil. log dif & 4869 & 0.00 & 0.03 & -0.40 & -0.01 & 0.00 & 0.01 & 0.23 & -0.99 & 20.31 \\
Equinor. log dif & 4869 & 0.00 & 0.02 & -0.20 & -0.01 & 0.00 & 0.01 & 0.17 & -0.21 & 6.72 \\
Petrobras. log dif & 4869 & 0.00 & 0.03 & -0.37 & -0.02 & 0.00 & 0.02 & 0.26 & -0.53 & 9.58 \\
PetroChina. log dif & 4869 & 0.00 & 0.02 & -0.15 & -0.01 & 0.00 & 0.01 & 0.14 & -0.01 & 5.41 \\
\hline
\end{tabular}

\section{AUTHOR'S ADDRESS}

Josef Pavlata, Faculty of Business and Economics, Mendel University in Brno, Zemědělská 1, 61300 Brno, Czech Republic, e-mail: 44977@node.mendelu.cz

Petr Strejček, Department of Finance, Faculty of Business and Economics, Mendel University in Brno, Zemědělská 1, 61300 Brno, Czech Republic, e-mail: petr.strejcek@mendelu.cz

Peter Albrecht, Department of Finance, Faculty of Business and Economics, Mendel University in Brno, Zemědělská 1, 61300 Brno, Czech Republic, e-mail: peter.albrecht@mendelu.cz

Martin Širůček, Department of Finance, Faculty of Business and Economics, Mendel University in Brno, Zemědělská 1, 61300 Brno, Czech Republic, e-mail: martin.sirucek@mendelu.cz 